\title{
DETERMINANTS OF QUALITY OF LIFE OF THE ELDERLY WITH DEMENTIA: A SYSTEMATIC REVIEW
}

\author{
Annisa Nur Fauziyah, Bhisma Murti \\ Masters Program in Public Health, Universitas Sebelas Maret
}

\begin{abstract}
Background: Dementia is a chronic condition caused by progressive changes in the brain. It can lead to loss of memory and cognitive function. As a dementia cure is not available, maintaining, and maximizing quality of life (QoL) is an important treatment goal in caring for people with dementia. The purpose of this study was to systematically review the determinants of quality of life of the elderly with dementia.

Subjects and Method: A systematic review was conducted by searching published articles from January 2016 to August 2019. The articles were obtained from ScienceDirect, PubMed, and Wiley Online Library databases. 9 articles were met inclusion criteria for this study. The data were analyzed by PRISMA flow diagram.

Results: Determinants of quality of life of the elderly with dementia included demography, religiosity, psychological, social, environmental factors, daily physical activity, chronic disease, and quality of health care.

Conclusion: Demography, religiosity, psychological, social, environmental, daily physical activity, chronic disease, and quality of health care, determine the quality of life of the elderly with dementia. The elderly with dementia required better health care and support to increase their quality of life.
\end{abstract}

Keywords: quality of life, dementia, elderly

Correspondence:

Annisa Nur Fauziyah. Masters Program in Public Health, Universitas Sebelas Maret. Jl. Ir. Sutami 36A, Surakarta 57126, Central Java. Email: annisafauziyaho3@gmail.com. Mobile: +6282335197211 . 